九州大学学術情報リポジトリ

Kyushu University Institutional Repository

\title{
Elicitor of the $\beta$-Thujaplicin Accumulation in Callus Cultures of Cupressus Lusitanica.
}

Inada, Satoko

Wood Chemistry Laboratory, Faculty of Agriculture, Kyushu University

Tsutsumi, Yuji

Wood Chemistry Laboratory, Faculty of Agriculture, Kyushu University

Sakai, Kokki

Wood Chemistry Laboratory, Faculty of Agriculture, Kyushu University

https://doi.org/10.5109/24044

出版情報：九州大学大学院農学研究院紀要. 38 (1/2)，pp.119-126，1993-12. Kyushu University バージョン：

権利関係 : 


\title{
Elicitor of the $\beta$-Thujaplicin Accumulation in Callus Cultures of Cupressus lusitanica. ${ }^{* 1}$
}

\author{
Satoko Inada, Yuji Tsutsumi and Kokki Sakai* ${ }^{2}$ \\ Wood Chemistry Laboratory, Faculty of Agriculture, \\ Kyushu University 46-08, Fukuoka 812, Japan \\ (Received July 30, 1993)
}

\begin{abstract}
The addition of yeast extract to callus cultures of Cupressus lusitanica leads to a large increase in the production of $\beta$-thujaplicin that acts as a phytoalexin of the treated cultures. $\quad \gamma$ - Thujaplicin was not formed in any appreciable amounts. The content usually reached $8-16 \mathrm{mg} / \mathrm{g}$ of dry weight of callus in 6 days of incubation after the addition of yeast extract. This accumulation of $\beta$-thujaplicin suggested the presence of elicitor components in the yeast extract. Therefore, the extract was fractionated by means of ethanol precipitation, ribonuclease treatment and complexation with the Fehling reagent. Some fractions of the extract actively induced the $\beta$ - thujaplicin accumulation in the Cupressus Zusitanica callus. The most effective fraction was purified about 50 - fold over unfractionated extract, and was a polysaccharide which was composed of mainly mannose, glucose, and to a lesser degree ribose residues.
\end{abstract}

\section{INTRODUCTION}

Plants frequently accumulate phytoalexins, low molecular weight toxins which inhibit the growth of microorganisms, in their tissues to express resistance to invading pathogens (Darvill and Albersheim, 1984). This response is regarded as one of the defence systems characteristic of plant cells that lack immune systems present in animal cells (Kurosaki, 1990). Some of elicitors which induce the phytoalexin formation originate from the microbial cell wall. Thus glucan fragments (Albersheim et al., 1981) and chitosan (Hadwiger and Beckman, 1980) were identified as elicitors of the phytoalexin production in soybeans and pea-pod tissues, respectively.

Some heart wood constituents are likely to be phytoalexins because they are of the fungicidal and insecticidal natures and are sometimes formed in the uninjured sapwood tissue adjacent to the damaged cells when trees are damaged (Hart, 1989). Therefore, if phytoalexin production in cultured cells of softwood species can be controlled by elicitation, that would be a good model system for the biochemical study of heart wood constituents.

Recently Sakai et al. (1993) reported that $\beta$-thujaplicin, a typical heart wood constituent of the Cupressaceae species, was accumulated in the callus culture of Cupressus lusitanica when treated with yeast extract and culture filtrates of some fungi. In this paper we deal with the partial purification and characterization of the elicitor present in yeast extract for the $\beta$-thujaplicin production in C. lusitanica callus cultures,

*1: Part IV in a series "Secondary Metabolites in Cell Cultures in Woody Plants"

${ }^{*}$ 2: Corresponding author 


\section{MATERIALS AND METHODS}

\section{Identification of phytoalexin}

Three grams of Thuja plicata wood meal were extracted with $100 \mathrm{ml}$ of methanol. The methanol extract was evaporated and the residue successively subjected to silica gel column chromatography and a preparative thin layer chromatography using benzene-methanol -acetic acid (20:1:1) as an eluent. Thujaplicins were visualized by spraying with iron (III) acetate upon thin layer chromatography plates. The thujaplicinrich fraction was subjected to ${ }^{1} \mathrm{H}$ NMR. The spectrum was recorded in $\mathrm{CDCl}_{3}$ on a spectrometer JNM-GSX 400 using tetramethylsilane as an internal standard and the composition of $\alpha-, \beta-$ and $\gamma-$ thujaplicins was estimated. Identification of the phytoalexin in C. lusitanica callus was performed by means of co - chromatography with the wood thujaplicins on gas chromatography (GC). GC column and temp. : Neutrabond $-1(25 \mathrm{~m} \times 0.53 \mathrm{~mm}$ I.D. $)$ and at $130-180^{\circ} \mathrm{C}$ with program rate $2^{\circ} \mathrm{C} / \mathrm{min}$.

\section{Purification of the elicitor}

\section{1) Ethanol precipitation}

Commercial yeast extract (DIFCO) was used throughout this work. For the purification of the elicitor from yeast extract, we followed the ethanol precipitation procedure of Hahn et al. (1978). An aqueous solution of yeast extract (150 g/l) was fractionated into the $80 \%$-ethanol-soluble (YE2) and the precipitate (YE3). The latter was dissolved in $1000 \mathrm{ml}$ of water, and fractionated into the $60 \%$-ethanol soluble (YE4) and the precipitate (YE5). Unfractionated yeast extract was designated as YE1.

Sugar and protein contents in each fraction were determined by the phenol -sulfuric acid method (Dubois et al., 1956) and with a protein assay kit with standard II (BIORAD Lab.), respectively.

\section{2) Enzymatic treatment and acid hydrolysis of YE5}

YE5 (180 mg/ $10 \mathrm{ml}$ ) was incubated with $2.5 \mu \mathrm{g}$ (905 units) of ribonuclease (Worthington Biochemical Co.) in $5 \mathrm{ml}$ of $0.2 \mathrm{M}$ Tris- $\mathrm{HCl}$ buffer $(\mathrm{pH} 7.5), 2.5 \mathrm{ml}$ of $0.02 \mathrm{M}$ EDTA and $2.5 \mathrm{ml}$ of reagent grade water for $24 \mathrm{~h}$ at $37^{\circ} \mathrm{C}$. The enzymatic treatment was terminated by autoclaving for $2 \mathrm{~min}$ at $120^{\circ} \mathrm{C}$. After centrifuging the reaction mixture, the supernatant was evaporated to $10 \mathrm{ml}$, applied to a Sephadex G-75 column $(35 \mathrm{~cm} \times 3 \mathrm{~cm}$ I.D.) and eluted with reagent grade water at $1.7 \mathrm{ml} / \mathrm{min}$. Absorbance was monitored at $280 \mathrm{~nm}$, and at $490 \mathrm{~nm}$ by the phenol -sulfuric acid method. The fractions eluted from 51 to $136 \mathrm{ml}$ of elution volume and from 136 to 225 $\mathrm{ml}$ were separately collected and designated as YE5A and YE5B, respectively (cf. Fig. 3).

For acid hydrolysis, $180 \mathrm{mg}$ of YE5 was heated for $1 \mathrm{~h}$ at $120^{\circ} \mathrm{C}$ in $10 \mathrm{ml}$ of $3 \%$ trifluoroacetic acid which was vacuum-evaporated after the hydrolysis.

\section{3) Fractionation with the Fehling reagent}

The elicitor -active fraction (YE5A) was further fractionated into soluble and precipitate fractions with the Fehling reagent according to the method of Peat et al. (1961). The supernatant (YE5Aa) and precipitate (YE5Ab) were separately acidified to $\mathrm{pH} 3.0$ with $1 \mathrm{M} \mathrm{HCl}$, and then chromatographed on the above-mentioned Sephadex 
G-75 column to remove inorganic salts. The fractions, which eluted between 51 and 136 $\mathrm{ml}$, were collected.

\section{Analysis of the sugar composition}

The elicitor fractions $(2-15 \mathrm{mg})$ were hydrolyzed in $72 \% \mathrm{H}_{2} \mathrm{SO}_{4}(2 \mathrm{ml})$ at $30^{\circ} \mathrm{C}$ for 1 hour and then the reaction mixture was diluted and hydrolyzed in $3 \% \quad \mathrm{H}_{2} \mathrm{SO}_{4}$ at $100^{\circ} \mathrm{C}$ for 8 hours according to the method of Selvendran et al. (1979).

The sugar moieties were converted to alditol acetates according to Sutherland et al. (1992) except where the reduction was performed with $7 \mathrm{mg} \mathrm{NaBH}$ for $90 \mathrm{~min}$ and that $0.05 \mathrm{ml}$ of pyridine and $0.1 \mathrm{ml}$ acetic anhydride were employed for acetylation. A GC analysis was carried out with 3\% ECNSS-M on Gas Chrom Q (100-120 mesh) in a glass column $(2 \mathrm{~m} X \mathbf{3 . 0} \mathrm{mm})$ at $170-200^{\circ} \mathrm{C}$ with a program rate of $2^{\circ} \mathrm{C} / \mathrm{min}$.

\section{Culture condition}

The cell culture of C. lusitanica (Sakai et al., 1993) grown on the Gamborg B5 medium (Gamborg et al., 1968) containing $2 \%$ sucrose, $10^{-5} \mathrm{M}$ NAA, $10^{-8} \mathrm{M}$ BAP and $0.27 \%$ gellan gum in the dark at $25^{\circ} \mathrm{C}$ was transferred to a fresh medium every $3-4$ weeks. Prior to the start of the present experiment the cultures had been maintained in vitro for more than three years.

\section{Assay for elicitor activity}

A $1 \mathrm{ml}$ aliquot of solution of each yeast extract fraction was added dropwise onto about $1 \mathrm{~g}$ of C. Zusitanica callus on the growth medium described above. Water $(1 \mathrm{ml})$ was added for the control experiments. After a six -day incubation, the callus was pulverized with a pestle and mortar and extracted twice with $6 \mathrm{ml}$ of ethyl acetate. $\beta$ Thujaplicin content in the ethyl acetate extract was determined by means of GC after decomposing thujaplicin-iron complexes by treating the extract with a mixture of $6 \mathrm{M}$ $\mathrm{HCl}$ and $10 \%$ potassium ferrocyanide. A GC analysis was performed as described above for the phytoalexin identification.

\section{RESULTS AND DISCUSSION}

\section{Identification of phytoalexin}

${ }^{1} \mathrm{H}$ NMR spectra indicated that a thujaplicins mixture isolated from T.plicata contained P-and y-thujaplicins (about 1:2) but no a-thujaplicin. Gas chromatograms of the thujaplicin mixture and methanol extracts from $C$. hsitanica callus are shown in Fig. 1. It is noteworthy that $C$. Zusitanica callus culture specifically accumulated $\beta-$ thujaplicin but almost no y-thujaplicin, even though Zavarin et al. (1967) reported the presence of both $\beta$ - and $y$ - thujaplicins in heartwood samples of C.lusitanica. $\beta$ Thujaplicin, a characteristic heartwood constituent of Cupressaceae species, possesses an antimicrobial activity which gives strong durability to wood (Trust et al., 1973) and this compound was produced in a considerable amount when C. Zusitanica callus was treated with some fungal culture filtrates or yeast extract (Sakai et al., 1993). Therefore, $\beta$-thujaplicin may be regarded as one of phytoalexins in C. Iusitanica callus and yeast extract is expected to contain an elicitor component. 


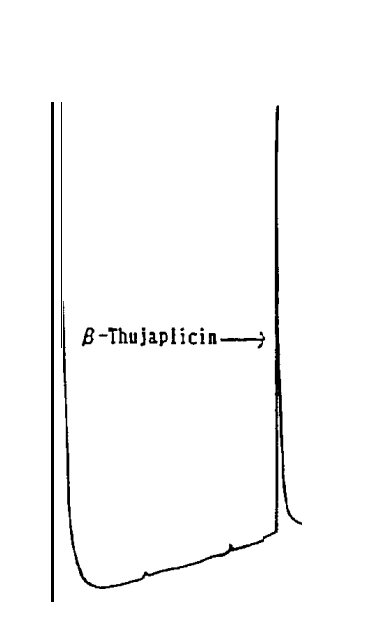

(A) Extract of C. Iusitanica callus treated with yeast extract

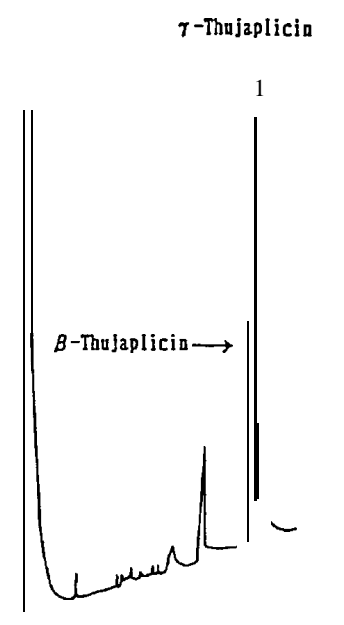

(B) Extract of T. Plicata heart wood

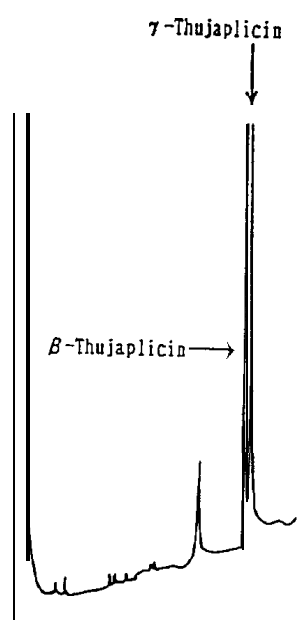

(C) Co-chromatography of $A$ and $B$

Fig. 1. Identification o phytoalexin.

\section{Purification of the elicitor from yeast extract}

\section{1) Ethanol precipitation}

The yeast extract solution was fractionally precipitated by changing the ethanol concentration of the solution. Thus, YE1 was designated as unfractionated yeast extract; YE2 and YE3 as 80\%ethanol soluble and insoluble, and; YE4 and YE5 as $60 \%$ ethanol soluble and insoluble, respectively.

Contents of $\beta$-thujaplicin in the callus treated with YE1 through YE5 are shown in Fig. 2. The elicitor activities of YE1, YE3 and YE5 were at almost the same level (8 $\mathrm{mg}$ of $\beta$-thujaplicin/d.w.g. of callus) whereas YE4 had rather weak activity $(5 \mathrm{mg} /$ d.w.g). YE2 possessed very weak elicitor activity $(1 \mathrm{mg} / \mathrm{d} . w . g)$. The weight of YE5 accounted for only $12 \%$ of unfractionated yeast extract YE1 (Table 1) in spite of its strong elicitor activity. This indicates that YE5 is the most purified fraction. Therefore, further purification of the elicitor was attempted with YE5.

\section{2) Enzymatic treatment and acid hydrolysis of YE5}

Yeast extract contains large amounts of nucleic acids and their fragments. YE5 contained as little as $0.6 \%$ protein in spite of its large absorptivity at $280 \mathrm{~nm}$ (Table 1). Furthermore, the protein content was not proportional to the absorptivity at $280 \mathrm{~nm}$ of each fraction. These results suggest that the substances responsible for absorption at $280 \mathrm{~nm}$ were not proteins but mainly nucleic acid derivatives. Accordingly YE5 was digested with a ribonuclease prior to the gel filtration chromatography to show if nucleic acids have any distinct effects on the elicitor activity of the yeast extract. Substances that absorbed at $280 \mathrm{~nm}$ were markedly depolymerized, indicating that these substances were ribonucleic acids, while molecular the weight distribution of 


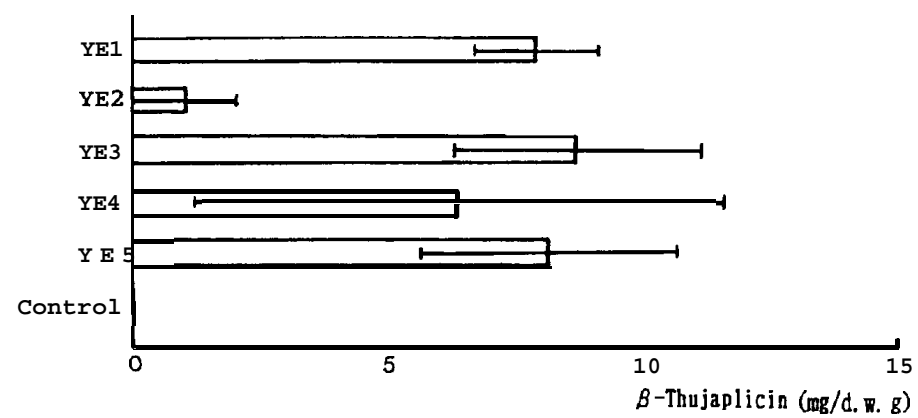

Fig. 2. Elicitor activity of YE1-YE5.

Note: Error bar shows standard deviation.

Table 1. Properties of fractions obtained by the ethanol-precipitaion method.

\begin{tabular}{ccccc}
\hline & Yield & $\begin{array}{c}\text { Sugar } \\
\text { content } \\
(\%)\end{array}$ & $\begin{array}{c}\text { Protein } \\
\text { content } \\
(\%)\end{array}$ & $\begin{array}{c}\text { Absorptivity } \\
\text { at } \mathbf{2 8 0} \mathrm{nm} \\
(1 / \mathrm{g} \cdot \mathrm{cm})\end{array}$ \\
\hline YE1 & 100.0 & 19.0 & 0.27 & 1.607 \\
YE2 & 61.3 & 11.2 & 0.26 & 1.838 \\
YE3 & 38.6 & 31.6 & 0.29 & 1.601 \\
YE4 & 27.5 & 18.2 & 0.16 & 1.375 \\
YE5 & 12.0 & 58.9 & 0.60 & 2.550 \\
\hline
\end{tabular}

polysaccharide was kept unchanged (Fig. 3). Consequently, we successfully fractionated YE5 into a polysaccharide-rich fraction (YE5A), and another fraction which was rich in nucleic acid fragments (YE5B). Ribonuclease-treated YE5 held its elicitor activity the same as untreated YE5. The polysaccharide-rich fraction, YE5A, induced the $\beta$-thujaplicin accumulation in callus at the same level as YE5 did. The elicitor activity of YE5B was rather small (Fig. 4).

Both polysaccharide and nucleic acid in YE5 were markedly degraded by acid hydrolysis (data not shown). Content of $\beta$-thujaplicin in C. lusitanica callus treated by acid hydrolyzed YE5 was as small as that in control (Fig. 4). This suggests that elicitor in YE5 was completely degraded by acid hydrolysis. These results suggest that the elicitor in yeast extract was polysaccharide and support the observations of Brodelius et al. (1989), Hahn et al. (1978) and Sumaryono et al. (1991).

\section{3) Fehling precipitation}

It was confirmed by Phaff et al. (1977) that a large amount of mannan was present in yeast extract. We, therefore, employed the Fehling precipitation in order to fractionate YE5A into precipitate (YE5Ab) and supernatant (YE5Aa) fractions. The non-precipitated fraction, YE5Aa, elicited the accumulation of $6 \mathrm{mg} / \mathrm{d}$.w.g of $\beta$ thujaplicin which was about half the elicitor activity of YE5A (Fig. 4). The decrease of elicitor activity of YE5Aa as compared with YE5A is possibly due to the loss of a portion of YE5Aa during gel filtration on a Sephadex G 75 column for removing 


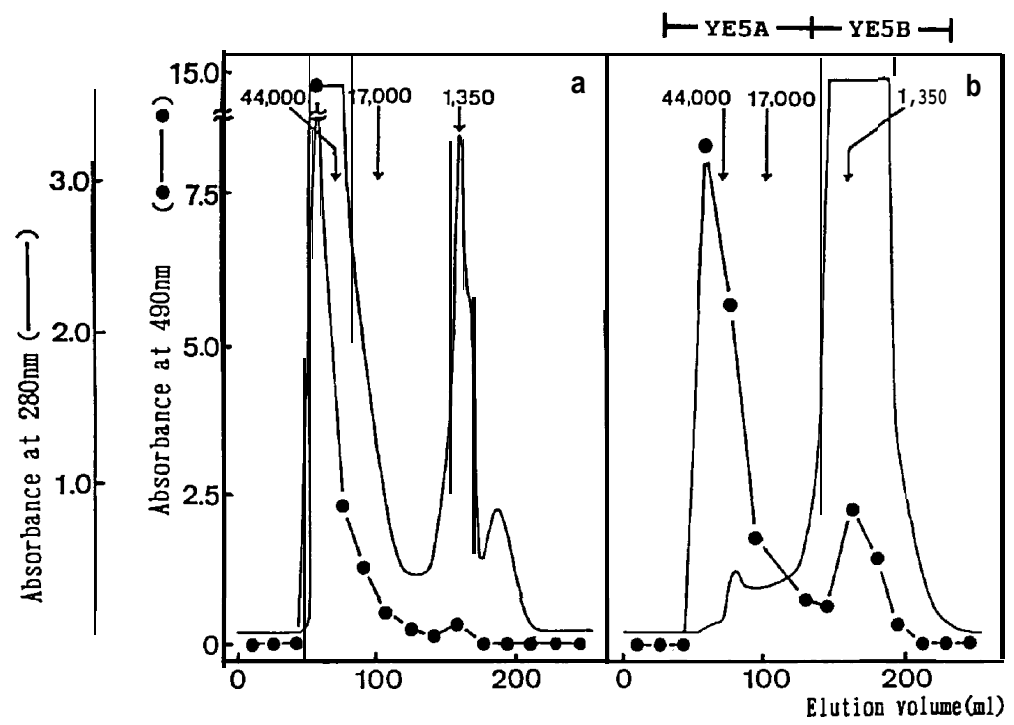

Fig. 3. Molecular weight distribution of YE5 treated with ribonuclease. Notes: Arrows $(\downarrow)$ designate elution volume of molecular weight markers.

a: YE5, b: YE5 treated with ribonuclease.

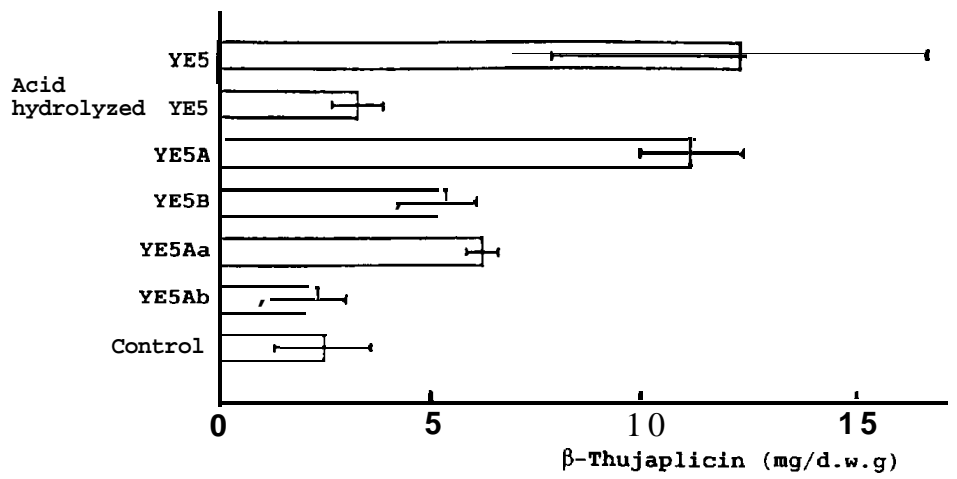

Fig. 4. Elicitor activity at different stages of purification. Note: Error bar shows standard deviation.

inorganic salts. YE5Ab which is considered to be mannan did not possess elicitor activity.

Figure 5 shows the dose-response of $\beta$ thujaplicin accumulation in $\mathrm{C}$. Iusitanica callus for the elicitor fractions at the different stages of purification. YE5Aa with the highest specific activity stimulated the accumulation of about $11 \mathrm{mg}$ of $\beta$-thujaplicin/ d.w.g at the concentration of $0.2 \mathrm{mg} / \mathrm{ml}$. On the other hand, $10 \mathrm{mg} / \mathrm{ml}$ of YE1 stimulated about $12 \mathrm{mg}$ of $\beta$ - thujaplicin /d.w.g accumulation. Thus, YE5Aa was purified about 50-fold over unfractionated yeast extract. 


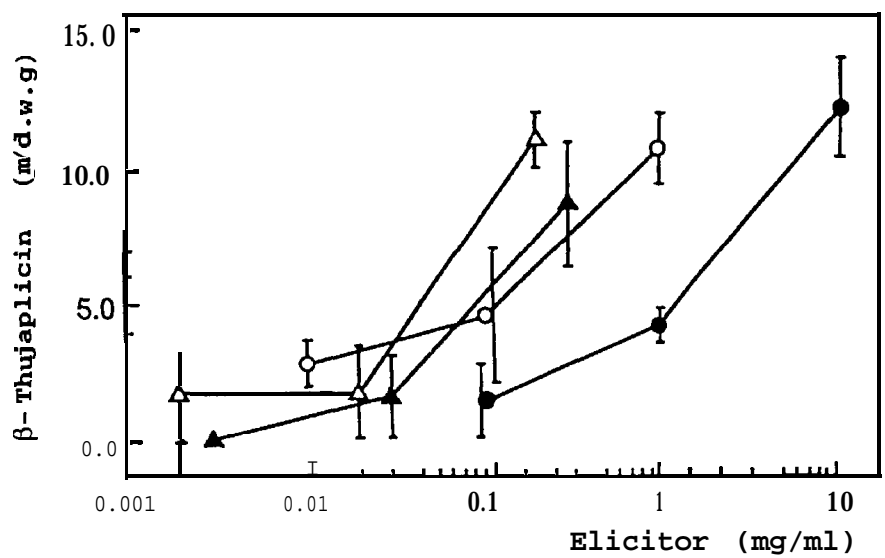

Fig. 5. Dose-response curves of elicitor fractions at different stages of purification.

Note: Error bar shows standard deviation.

Legend: $:$ YE1, $\bigcirc:$ YE5, A: YE5A, $\triangle$ :YE5Aa.

Table 2. Sugar composition of elicitor fractions.

\begin{tabular}{|c|c|c|c|c|c|}
\hline & \multirow{2}{*}{$\begin{array}{l}\text { Yield" } \\
(\%)\end{array}$} & \multirow{2}{*}{$\begin{array}{c}\text { Sugar content } \\
(\%)\end{array}$} & \multicolumn{3}{|c|}{ Sugar composition (\%) } \\
\hline & & & Mannose & Glucose & Ribose \\
\hline YE5A & 3.3 & 76.1 & 85.3 & 12.4 & 2.4 \\
\hline YE5Aa & 0.8 & 99.6 & 50.9 & 45.4 & 3.7 \\
\hline $\mathrm{YE} 5 \mathrm{Ab}$ & 2.0 & 91.2 & 94.4 & 5.6 & Trace \\
\hline
\end{tabular}

1) Yeild is expressed as the percent on yeast extract.

\section{Analysis of the sugar composition}

The biotic components with elicitor activity are heterogeneous in chemical structure and size as elicitors of different structures have been isolated not only from phytopathogenic fungi but also from the cell walls of plants themselves (Darvill and Albersheim, 1984).

Sugar compositions of elicitor fractions were, therefore, analyzed and listed in Table 2. The most purified fraction, YE5Aa, contained mannose, glucose, and ribose residues in the ratio of 51:45:4. This result leads to the conclusion that the elicitor of the $\beta$-thujaplicin accumulation in C. lusitanica callus isolated from yeast extract may be a glucomannan. It was reported that yeast extract elicited accumulation of rosmarinic acid in Orthosiphon aristatus cell suspension cultures (Sumaryono et al., 1991). Two elicitors in yeast extract were shown to be carbohydrate polymers having molecular weights of ca. 22,000 and 7,000 and containing mainly mannose, glucose, and to a lesser degree galactose. These elicitors of the rosmarinic acid production are quite similar to the elicitor of the $\beta$-thujaplicin accumulation in C. lusitanica callus, although there is a small difference in their sugar compositions.

The elicitor -inactive fraction, YE5Ab, was composed of almost solely mannose. This suggests that mannan is not elicitor of $\beta$-thujaplicin accumulation. This was 
further confirmed by the fact that commercial yeast mannan did not show any detectable elicitor activity.

\section{ACKNOWLEDGEMENT}

We are indebted to Dr. M. Yatagai for providing ${ }^{1} \mathrm{H}$ NMR spectra of $\alpha^{-}, \beta$ - and $y$-thujaplicins. Financial aid from the Scientific Research Fund (No. 03454081) of the Ministry of Education, Japan is gratefully appreciated.

\section{REFERENCES}

Albersheim, P., A. G. Darvill, M. Mcneil, B. S. Valent, M. G. Hahn, G. Lyon, J. K. Sharp, A. E. Desjardins, M. W. Spellman, L. M. Ross, B. K. Robertsen, P. Aman and L. E. Franzen 1981 Structure and function of complex carbohydrates active in regulating plant - microbe interactions. Pure and $A p p l$. Chem., 53: 79-88

Brodelius, P., M. A. Collinge, C. Funk, K. Gugler and I. Marques 1989 Studies on alkaloid formation in plant cell cultures after treatment with a yeast elicitor. In "Primary and secondary metabolism of plant cell cultures II", ed. by G. W. K. Wolfgang, Springer-Verlag pp. 191-199

Darvill, A. G. and P. Albersheim 1984 Phytoalexins and their elicitors - A defense against microbial infection in plants. Ann. Rev. Plant Physiol., 35: 243-275

Dubois, M., K. A. Gilles, J. K. Hamilton, P. A. Rebers and F. Smith 1956 Colorimetolic method for determination of sugar and related substances. Anal. Chem., 28: 350-356

Gamborg, 0. L., R. D. Miller and K. Ojima 1968 Nutrient requirements of suspension cultures of soybean root cells. Exp. Cell Res., 50: 151-156

Hadwiger, L. A. and J. M. Beckman 1980 Chitosan as a component of pea -Fusarium solani interactions. Plant Physiol., 66: 205-211

Hahn, M. G. and P. Albersheim 1978 Host-pathogen interaction. Plant Physiol., 62: 107-111

Hart, J. H. 1989 The role of wood exudates and extractives in protecting wood from decay. In "Natural products of woody plants II", ed. by J. W. Rowe, Springer-Verlag pp. 861-880

Kurosaki, F. 1990 Defence reaction and information transfer mechanisms in higher plants. The heredity, 44: 45-49 (in Japanese)

Peat, S., W. J. Whelan and T. E. Edwards 1961 Polysaccharides of baker's yeast Part IV. Mannan. J. Chem. Soc., 29-34

Phaff, H. J. 1977 Enzymatic yeast cell wall degradation. Adv. Chem. Ser., 160: 244-282

Sakai, K., K. Kusaba, Y. Tsutsumi and T. Shiraishi 1993 Secondary metabolites in cell cultures of woody plants III. Mokuzai Gakkaishi, in press

Selvendran, R. R., J. F. March and S. G. Ring 1979 Determination of aldoses and uronic acid content of vegetable fiber. Anal. Biochem., 96: 282-292

Sumaryono, W., P. Proksh, T. Hartmann, M. Nimtz and V. Wrey 1991 Induction of rosmarinic acid accumulation in cell suspension cultures of O rthosiphon aristatus after treatment with yeast extract. Phytochemisty, 30: 3267-3271

Sutherland, J. B., A. L. Selby, J. P. Freeman, D. W. Miller and C. E. Cerniglia 1992 Identification of xyloside conjugates formed from anthracene by Rizoctoria solani. Mycol. Res., 96: 509-517

Trust, T. J. and R. W. Cooms 1973 Antibacterial activity of P-thujaplicin. Can. J. Microbiol., 19: $1341-1346$

Zavarin, E., L. V. Smith and J. G. Bicho 1967 Tropolones of Cupressaceae-III. Phytochemisty, 6: $1387-1394$ 